\title{
GUIDE FOR THE DESIGN AND CALCULATION OF VIA FERRATA
}

\author{
Carlos Martín Díaz \\ Industrial Engineering, University of Cadiz / University Carlos III of Madrid \\ Carlos Mora Sepúlveda \\ Road, Canal and Port Engineering from the Alfonso X El Sabio University \\ María Dolores Rubio-Cintas \\ Industrial Engineering, University of Malaga / University of Cadiz \\ Kissi Benaissa \\ ENSAM of Casablanca, University of Hassan II, Morocco
}

\begin{abstract}
A via ferrata (from the German "klettersteig", hereinafter VF) is a sports route located on forest and mountains vertical rock walls equipped with steps, chains, artificial dams, bridges and other fixed elements and which have a steel cable (safety cable) all the way along allowing users to secure their progress and avoid possible falls [1]. This article aims to analyse the state of the art of the VF sector in Spain, especially in terms of the regulations of obligatory compliance, in addition to defining the basic characteristics of the installations to ensure that these are safe for users, providing a previously non-existent summary of the most important recommendations regardless of the country where they are installed.

Keywords: Via Ferrata, anchorage points, fall factor, safety cable, amplification factor Cite this Article: Carlos Martín Díaz, Carlos Mora Sepúlveda, María Dolores RubioCintas and Kissi Benaissa, Guide for the Design and Calculation of Via Ferrata, International Journal of Mechanical Engineering and Technology, 9(8), 2018, pp. 264-276.

http://www.iaeme.com/IJMET/issues.asp?JType=IJMET\&VType=9\&IType=8
\end{abstract}

\section{INTRODUCTION}

There is currently increased interest throughout Europe and Spain in practising forest and mountain sports such as VF routes; as a result of this, the number of installations built in the last 5 years in Spain is nearly $60 \%$ of the total, which is estimated to be around two hundred $[1,2]$. Because of this boom, various jobs and professions have emerged in relation thereto, 
Guide for the Design and Calculation of Via Ferrata

such as VF installation companies, those dedicated to guided visits of the installations and certification and inspection companies, amongst others.

The main problem that arises when it comes to designing and sizing the various elements that make up a VF is the non-existence of specific regulations or legal texts to base the work on to ensure that the installation is correctly designed and installed [3]. As a result of this lack of regulation, we find ourselves in a situation of being outside the law: there are no clear legal requirements, limitations or obligations when it comes to designing the various VF elements and each technician designs them to the best of their understanding.

\subsection{TYPES OF VIA FERRATA}

We can classify VFs based on two criteria: according to the construction method (A) and according to their purpose (B). As regards the first criteria, these are distinguished according to whether or not they have been built using the classic method (A1), which allows the use of a tightened or non-tightened system, or the French method (A2), which uses rings to attach a cable to the anchorage points. As regards the second criteria, their purpose on the one hand there is the classic VF (B1) which seeks an easy, logical route across a wall to reach the end, normally a peak, and on the other there is the sports VF (B2) which seeks to take maximum advantage of the most interesting points of the wall and the spectacular nature of the route, with collapsed sections and a wide variety of elements, which sometimes include long bridges and zip lines. In many cases, the final destination or peak is secondary and not important.

There are other types of route across rocks such as assisted paths, assisted channels, vias cordatas and cable routes, which have certain similarities with VFs but differ from such in other respects [1,2 and 4] and are not covered in this article.

\subsection{MAIN ELEMENTS OF THE INSTALLATION}

We find different elements in a VF, some of which aim to help progression along such and others of which are for safety itself.

The main elements that guarantee users' safety along the whole route and must always be present in a VF from start to finish are the safety cable and its respective anchorage points to the rock. At the same time, the elements that allow progress along the VF are the steps (looped and protruding iron bars) and handles, generally built using U-shaped corrugated steel bars and which are anchored to the rock in the same way as the anchorage points for the cable. You can also find ladders and/or nets, but these are less common.

There is another series of optional elements to progress along a VF, which we will not go into, such as bridges and zip lines, which are used to make the route more spectacular, avoid level differences and bridge gaps to connect different areas. There are various different types of bridge depending on the number of cables these include; Nepalese (two cables) or Tibetan bridges (three cables), in addition to board bridges. Zip lines in turn can also be divided into ascending, descending or mixed. Both bridges and zip lines will always be accompanied by the safety cable which will be independent from the cables that make these up and give them their strength $[1,2,3]$.

\subsection{CONNECTION ELEMENTS TO THE VÍA FERRATA}

In addition to the elements that make up the VF, the choice and correct use of the various elements of Personal Protection Equipment (hereinafter, PPE) is of vital importance to guarantee connection to the cable and therefore users' safety during use. Amongst the main ones, we would highlight the following four: the harness (1), the purpose of which is to stop or brake free falls, and which must always comply with regulation UNE-EN 361: Safety harness [5]. Helmets (2) protect us from the falling of objects and/or blows, the helmet chosen 
Carlos Martín Díaz, Carlos Mora Sepúlveda, María Dolores Rubio-Cintas and Kissi Benaissa

must comply with either the regulations for helmets in industry [6] or those for helmets for mountain climbers [7]. Carabiners (3) specially marked with the letter K (from the German Klettersteig, VF) and regulated by regulation UNE EN 12275:2013 - Mountaineering and climbing equipment. Specific carabiners [8] for VFs.

But if there is one element that is essential, that would be the shock absorber (4), the joining element between the user and the VF cable and the role of which is fundamental so that the user does not suffer injury after the arresting of a fall, in limiting the maximum stress the human body receives to $6 \mathrm{kN}$. For this purpose, this element must comply with specific regulations for VFs, standard UNE-EN 958:2007+A1:2011 [9].

There are other PPE such as the use of gloves, adequate footwear and others [10], which we will not go into in more detail.

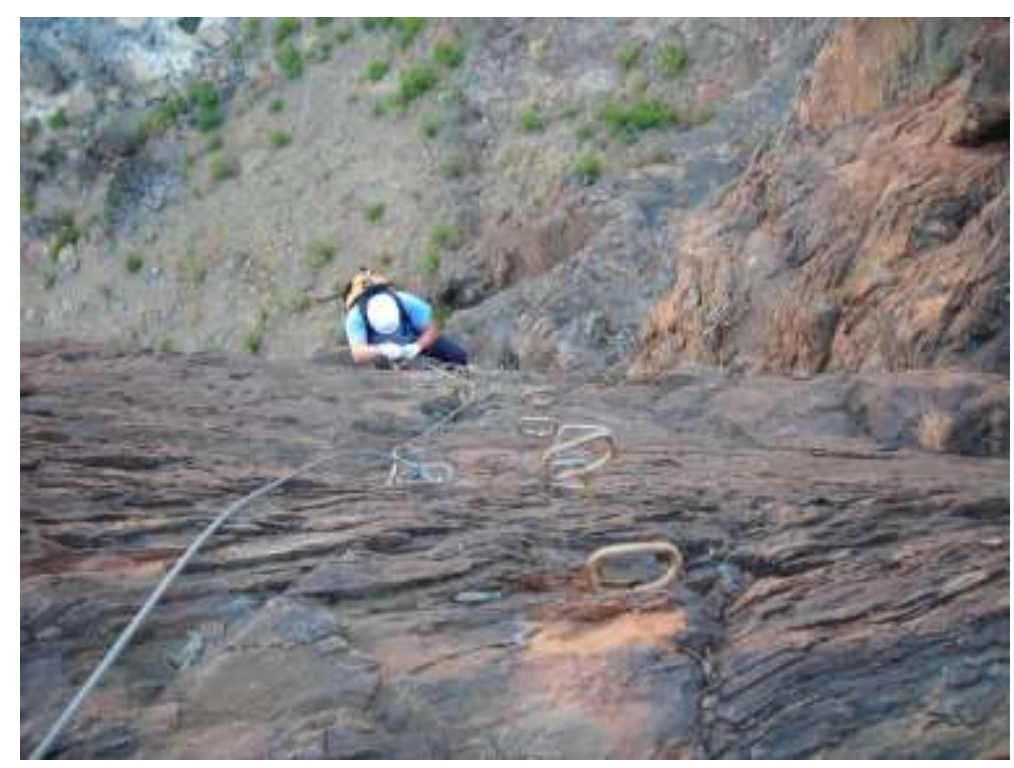

Carboné José. Primera Luna Via Ferrata. Safety cable and anchorage points. Las Palmas de Gran Canaria, 2010

\section{MATERIALS \& METHODS}

The lack of a specific standard on design and assembly of VF has led us to carry out important research on texts related to VF and existing publications, most of them with a sporting character. The main databases of the European standardization agencies (AENOR, AFNOR, DIN.) and associations of the world of mountaineering and climbing (the German Alpine Club and the Austrian Board of Mountain Safety) have been consulted too. Technical projects of VF built or under construction in Spain have also been analyzed. Finally, our experience of over 15 years as engineering designing, building and reviewing protection systems against falls from height both in nature (so-called VF) and industrial facilities (lifelines), has allowed to reach the results exposed.

\section{RESULTS \& DISCUSSION}

\subsection{URRENT APPLICABLE REGULATIONS}

After consulting with various regulating and certification organisms on a global scale such as AENOR Spain, AFNOR in France, DIN in Germany, UNI in Italy, ANSI in the US and associations like the UIAA, FEDME and FAM, we came to the conclusion that there is no specific common standard of obligatory compliance regarding the construction and/or design 
of VFs recognised on a global scale and of generalised use. The professionals of the sector say that AFNOR had a project to draft a standard which finally never took place.

As there is no legal document to comply with when it comes to certifying that a VF is correctly built, does that mean we have no text to help us when deciding on the diameters, strengths, dimensions, materials, etc. of the various elements that make up the installation? Not exactly. There are regulations that can be applied (in the majority of cases only partially) for the purposes being sought here, but it is true that not in such a simple and clear way as with a manual or specific standard for the case in question [2].

The standard that comes closest to the application of VFs is UNE-EN 15567 on the construction and safety requirements for recreational activities with an acrobatic route at height [11], although we consider it to be only partially valid as it does not consider all the elements we have indicated make up a VF.

When it comes to the design and calculation of the basic safety elements of the installation, cable and anchorage points, we recommend using standards UNE-EN 959 for anchorage points in rock [12] and UNE-EN 12385 for steel cables [13].

Other helpful standards for consultation are those that certify lifelines or anchorage lines, UNE-EN795/2012, for rigid or flexible horizontal or vertical systems [14, 15, 16]. A lifeline is not a VF but does have important similarities with them and the recommendations regarding testing after installation are very useful. Other reference standards for testing are UNE-EN 12572-1 and UNE-EN 12572-2 for artificial climbing structures [24, 25].

Where the installation includes a zip line, standard UNE-EN 1176-4 covers safety requirements and additional testing methods specifically for zip lines and provides a calculation method. But take care; said standard indicates that it is only applicable to children's installations, but as we say, it can serve as a guide [17].

\subsection{LOADS}

In order to calculate the anchorage points and cable in a VF it is essential to first assess the loads the system will be subject to. To do this, the working load and maximum load values that will be transferred thereto must be established. The working load is understood as the load the user will transfer to the VF through the normal use thereof, i.e., grip, progress in ascending and descending the steps and while stationary on the anchorage points. The VF must be capable of bearing said load with no problem whatsoever and additionally, the elements that make up the system must suffer no plastic deformation. In the event of a fall or accident, a significantly greater load than the working load will be applied to the VF for a short period of time; this load will be defined as the maximum load. In this case, some plastic deformation of the elements shall be tolerated but not the breakage thereof (logically after a fall the VF must be checked and any damaged elements replaced).

To determine said loads, the German Alpine Club and the Austrian Board of Mountain Safety performed the analytic and experimental studies detailed below in 4.2.1. And 4.2.2. [4].

\subsubsection{Analytic expression}

The following expression is used to estimate the stresses received by the anchorage points when loads are applied to the system, (E1). The variables that affect the result are the force applied (Kgf), the length of the span of cable (m) and the deflection produced in the cable in applying said load (m). We can distinguish between two main terms in the equation; the force applied and the amplification factor. The latter sums up the variables defined above in a single value. 
Carlos Martín Díaz, Carlos Mora Sepúlveda, María Dolores Rubio-Cintas and Kissi Benaissa

\begin{tabular}{|c|c|}
\hline Xspan & Fanchorage $=$ Fapplied $*$ Amplification factor \\
Ydeflection & $=$ Fapplied $* \frac{1}{2} \sqrt{1+\left(\frac{\text { Xspan }}{2 * \text { Ydeflection }}\right)}$ \\
\hline
\end{tabular}

Based on the above expression and looking exclusively at the amplification factor, we will check how said factor varies when the deflection produced in the span of cable varies when we apply a certain load. As an example, a span of $4 \mathrm{~m}$ (Xspan) is established and the deflection (Ydeflection) varies from $0.05 \mathrm{~m}$ to $0.4 \mathrm{~m}$. The results are shown in table 01, where we can see that the greater the deflection in the span of cable, the lesser the amplification factor of the load applied thereto.

Table 1 Example for the calculation of the amplification factor for a span of $4 \mathrm{~m}$ and deflection from $5 \mathrm{~cm}$ to $40 \mathrm{~cm}$.

\begin{tabular}{|c|c|c|c|c|c|c|c|c|}
\hline Ydeflection (m) & 0.05 & 0.10 & 0.15 & 0.20 & 0.25 & 0.30 & 0.35 & 0.40 \\
\hline Amplification factor & 20.0 & 10.0 & 6.7 & 5.0 & 4.0 & 3.4 & 2.9 & 2.5 \\
\hline
\end{tabular}

Another example is proposed and compared to the previous one, studying how the distance between the anchorage points affects the amplification factor. A distance of $3 \mathrm{~m}$ between anchorage points (Xspan) is assumed and it is established that the cable will show deflection within the range of $0.05 \mathrm{~m}$ to $0.40 \mathrm{~m}$ (Ydeflection) as in the above example. With this data and once again applying the E1 formula, we can see that for deflection of $10 \mathrm{~cm}$, the amplification factor comes to 7.5 whilst for deflection of $20 \mathrm{~cm}$, the amplification factor is 3.8 . In both cases we see that it is lower than in the first situation where the anchorage points were further apart.

Table 2 Example for the calculation of the amplification factor for a span of $3 \mathrm{~m}$ and deflection from $5 \mathrm{~cm}$ to $40 \mathrm{~cm}$

\begin{tabular}{|c|c|c|c|c|c|c|c|c|}
\hline Ydeflection $(\mathrm{m})$ & 0.05 & 0.10 & 0.15 & 0.20 & 0.25 & 0.30 & 0.35 & 0.40 \\
\hline Amplification factor & 15.0 & 7.5 & 5.0 & 3.8 & 3.1 & 2.5 & 2.2 & 1.9 \\
\hline
\end{tabular}

We can therefore conclude, according to the proposed analytical expression, E1, that by increasing the deflection (something that occurs in slacker systems, as we will see in point 6.1.2) and shortening the distance between anchorage points (a decision in the hands of the VF installation company), the stress transferred to the anchorage points is significantly reduced.

\subsubsection{Practical experiments (testing)}

Of the practical experiments carried out by the German Alpine Club, we will study the case of non-tightened systems (French method), as these are currently the most commonly used systems and also the safest, as in the event of a fall, the connectors do not impact directly with the anchorage points avoiding the possible breakage thereof.

In said practical experiment, two anchorage points are installed at a distance of $3.32 \mathrm{~m}$, joined by a cable the tightness of which can be adjusted using a tensioner and measured using a strain gauge. In this case, the initial strain is $0.3 \mathrm{KN}$. Once the testing was complete the following results were obtained: 
Guide for the Design and Calculation of Via Ferrata

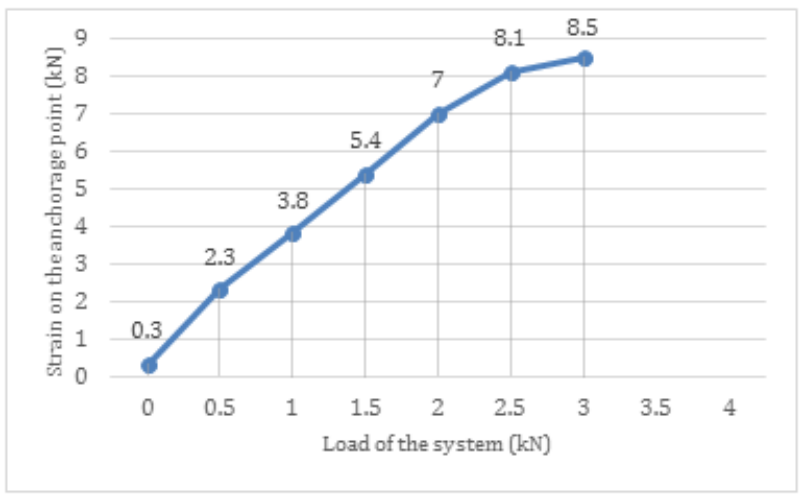

Graph 1 Relationship between the load applied to the system and the strain transmitted to the anchorage points.

The graph shows the force received at the anchorage point (ordinate axis) and the load applied to the system (abscissa axis). In this case where the system is slightly taught $(0.3 \mathrm{KN})$, deflection of $10-30 \mathrm{~cm}$ occurs.

In looking at the results obtained, we can see that within the range of loads applied to the system, stresses are obtained at the anchorage point that increase proportionally with a constant of approximately 3.5. Said constant shall be referred to as the amplification factor mentioned previously, as it coincides with the results obtained from the analytic expression.

\subsubsection{VF calculation loads}

Once the amplification factor mentioned in the previous section has been determined, the load as a result of progression, which occurs, for example, when a person is hanging from a cable or resting on an anchorage point, must be defined. The load transmitted by the climber is within the range of 0.5-1.5 times their weight, i.e., an average nominal value of $1 \mathrm{KN}$ if we estimate the average weight of a person at around $80 \mathrm{Kg}[3,18]$. Therefore, using the expression (E1) for a non-tightened or little tightened system, the progression load applied to the system will be $3.5 \mathrm{KN}$ for maximum distances of $3.3 \mathrm{~m}$ between anchorage points.

The maximum load that should be received by an intermediate anchorage point following a fall in a section of the VF, as established by standard UNE-EN958, is 6KN [9]. This is the limit value beyond which a person's body begins to suffer damages following a fall, and this limit will be respected providing standardized shock absorbers are used to connect the person to the VF. In horizontal sections where the seriousness of a fall is logically lower, the load transmitted to the anchorage point will also be lower, taking a maximum value in this case of $3.5 \mathrm{KN}$, provided the distance between anchorage points does not exceed $3.3 \mathrm{~m}$ and the cable is tightened to $0.3 \mathrm{KN}$. The final anchorage points of a VF, in accordance with the standard on anchorage points for climbing, UNE-EN-959, will be $25 \mathrm{KN}$ in terms of radial load and $15 \mathrm{KN}$ in terms of axial load [12].

Table 3 Maximum calculation loads at anchorage points according to the type thereof.

\begin{tabular}{|c|c|c|c|}
\hline $\begin{array}{c}\text { TYPE OF } \\
\text { ANCHORAGE } \\
\text { POINT }\end{array}$ & \multicolumn{2}{|c|}{ CHARACTERISTICS } & $\begin{array}{l}\text { MAXIMUM CALCULATION } \\
\text { LOAD }\end{array}$ \\
\hline \multirow{2}{*}{$\begin{array}{l}\text { Intermediate anchorage } \\
\text { points }\end{array}$} & \multicolumn{2}{|c|}{ No free fall possible in section } & $3.5 \mathrm{KN}$ \\
\hline & \multicolumn{2}{|c|}{ Falls possible } & $6 \mathrm{KN}$ \\
\hline \multirow[b]{2}{*}{ Final anchorage points } & \multirow{2}{*}{$\begin{array}{l}\text { Value in accordance with } \\
\text { standards for anchorage points } \\
\text { for climbing }\end{array}$} & Radial load & $25 \mathrm{KN}$ \\
\hline & & Axial load & $\mathrm{N}$ \\
\hline
\end{tabular}


Carlos Martín Díaz, Carlos Mora Sepúlveda, María Dolores Rubio-Cintas and Kissi Benaissa

\subsection{THE CABLE}

When it comes to choosing a cable for the installation, the stresses it will have to bear (traction stresses) must be considered. These may be static (load suspended from the cable and the cable's own weight) and dynamic, those resulting from the inertia of the masses occurring during periods of acceleration. Dynamic stresses are not important for VFs as the cables are static.

To calculate these static cables, the necessary safety coefficient must be defined so that, in the event of random deviations from the expected loads, there is a margin that ensures that the stresses will remain below the breakage load thereof. Due to the similarity in the way they work, we will suppose that the VF cable is like a bracing cable, the safety coefficient of which varies between 3 and 4. [19]

Once we have defined the maximum static load and the safety coefficient, we can establish the cable's breakage load, which will act as the cable's maximum working load.

Calculated breakage load of the cable $=$ Safety coefficient $*$ Maximum static load (E2)

When it comes to choosing a type of cable from amongst the many manufacturers on the market, we recommend a braided type with an internal configuration of $6 \times 7,7 \times 7,6 \times 19$ or $7 \times 19$, in any case avoiding the use of cables in a spiral which could unravel in the event of breakage [2,4]. The cable material will normally be steel, although other materials like stainless steel or aluminium can also be chosen, but are more expensive. It must be galvanised to protect against corrosion and the use of plastic sleeves that favour the appearance of corrosion should be avoided.

Having established the type of cable and working load, it just remains to define the diameter thereof by consulting any manufacturer's table. We will select $8 \mathrm{~mm}$ cable in transversal and little used areas and $12-18 \mathrm{~mm}$ in more used areas and bridges and zip lines [4].

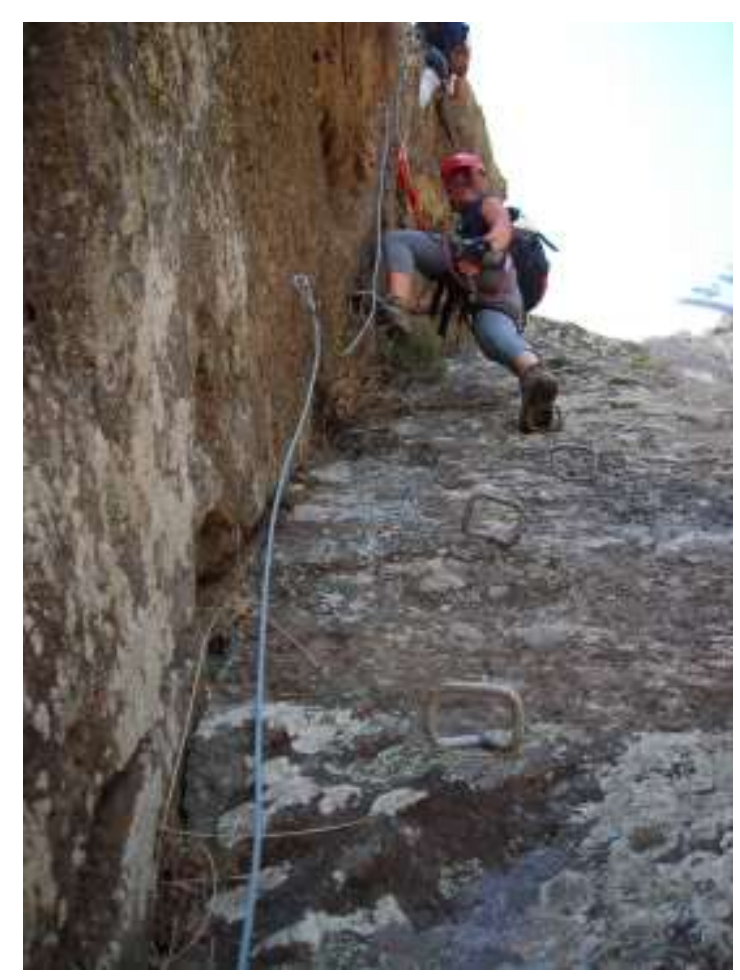

Carboné José. La Guagua Via Ferrata Safety cable and anchorage points. Las Palmas de Gran Canaria, 2011. 
Guide for the Design and Calculation of Via Ferrata

\subsection{ANCHORAGE POINTS OF THE VF}

When it comes to selecting and sizing the anchorage points, we must define a series of parameters such as the type of anchorage point and material thereof, the diameter, maximum permitted lever arm and the depth of penetration into the rock.

\subsubsection{TYPE AND MATERIALS}

The anchorage points are classified taking into account two criteria: according to their type (A), and according to their means of attachment to the rock (B). Regarding type, there are eyebolt type anchorage points (A1) where the cable passes freely through the eye and is not attached but instead can move freely, and U-type anchorage points (A2) where the cable is limited by the clamp $[4,20]$.

As regards the kind of attachment to the rock, there is the mechanical type (B1) where the attachment is through friction or interlocking, and the chemical type (B2) where "glue" or resin are used. For mechanical anchorage points, it is recommended that the drill bit be the same diameter as the anchorage point, whilst for chemical anchorage points, an additional 2$3 \mathrm{~mm}$ needs to be left on each side $[4,20]$.

The most common anchorage material is 500S class corrugated steel (high strength and weldability) and external protection against corrosion such as zinc or chrome plating is recommended. Another material that can be used is stainless steel, but this is more costly, and taking into account the high probability of the need to replace anchorage points due to blows from falling rocks or other environmental factors, this is not recommended from a maintenance point of view. All the anchorage points must be manufactured by an approved manufacturer, avoiding the use of home-made anchorage points.

\subsubsection{CALCULATIONS}

The diameter of the anchorage points and their relationship to the lever arm (distance between the cable and the wall, see figure 01) must be considered when sizing these. We have the following expression for this purpose:

$$
\text { Maximum strain stress: } \quad-(\mathrm{E} 3)
$$

$\sigma$ being the stress on the anchorage point $(\mathrm{N} / \mathrm{mm} 2), \mathrm{Mb}$ the moment of the applied force $\left(\mathrm{N}^{*} \mathrm{~mm}\right)$ and $\mathrm{Wb}$ the resistant module of the section $(\mathrm{cm} 3)$. Looking at figure 01 , we can deduce that $\mathrm{Mb}=\mathrm{F} * \mathrm{~L}$ lever arm (E4), and remembering that for a circular cross-section $\mathrm{Wb}$ $=(\pi / 32) * \mathrm{~d} 3 \quad(\mathrm{E} 5)$, we obtain the following expressions, establishing that $\sigma=\sigma \mathrm{e}$ (elastic limit)

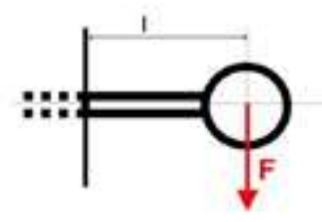

Figure 1 Length of lever arm.

- Maximum length of lever arm.

- $\quad$ Minimum anchorage point diameter $=$ (E6)

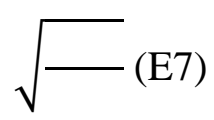


Carlos Martín Díaz, Carlos Mora Sepúlveda, María Dolores Rubio-Cintas and Kissi Benaissa

As an example of application using StE550 steel $(\sigma e=550 \mathrm{~N} / \mathrm{mm} 2)$, we obtain the following maximum lever arm lengths for each diameter of anchorage point, distinguishing these according to the force transmitted to the anchorage point.

Table 4 Maximum distances of the lever arm according to the diameter used and force transmitted to the anchorage point.

\begin{tabular}{|c|c|c|c|c|c|c|c|c|c|}
\hline Diameter of anchorage point (mm) & 16 & 18 & 20 & 22 & 24 & 26 & 28 & 30 & 32 \\
\hline $\begin{array}{c}\text { Force transmitted to the anchorage } \\
\text { point }(\mathrm{kN})\end{array}$ & \multicolumn{10}{|c|}{$3.5 \mathrm{kN}$} \\
\hline Maximum lever arm length (mm) & 63 & 90 & 123 & 164 & 213 & 271 & 339 & 417 & 506 \\
\hline $\begin{array}{c}\text { Force transmitted to the anchorage } \\
\text { point (kN) }\end{array}$ & \multicolumn{10}{|c|}{$6.0 \mathrm{kN}$} \\
\hline Maximum lever arm length (mm) & 37 & 52 & 72 & 96 & 124 & 158 & 198 & 243 & 295 \\
\hline $\begin{array}{c}\text { Force transmitted to the anchorage } \\
\text { point (kN) }\end{array}$ & \multicolumn{10}{|c|}{$25 \mathrm{kN}$} \\
\hline Maximum lever arm length (mm) & 9 & 13 & 17 & 23 & 30 & 38 & 47 & 58 & 71 \\
\hline
\end{tabular}

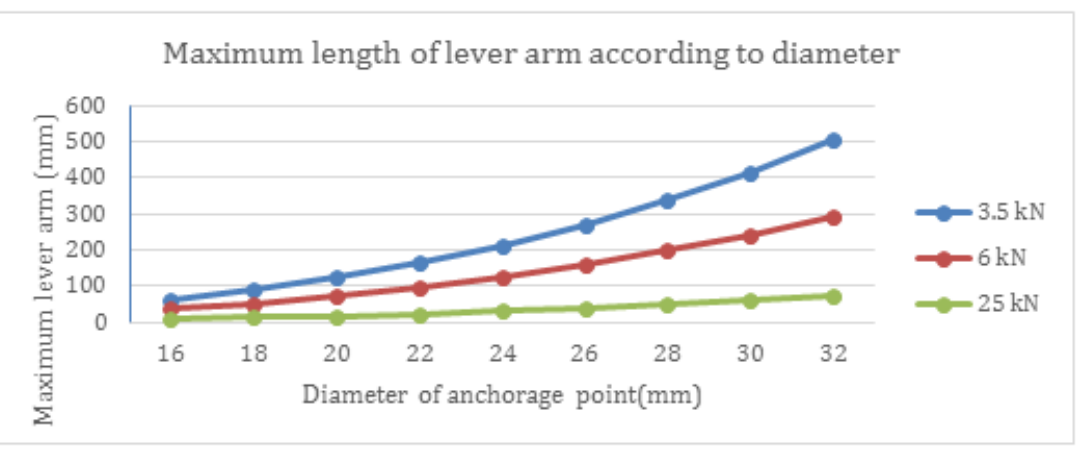

Graph 2 Maximum distances of the lever arm according to the diameter used and force transmitted to the anchorage point.

\subsubsection{DEPTH OF DRILL HOLE}

Finally, the depth of the drill hole to be made in the rock to install each anchorage point will be defined by the type of rock the VF is to be built on, its degree of cohesion or decomposition and finally, the distance between one anchorage point and the next in the rock [4].

Table 5 Depth of drill hole according to the type and quality of the rock, and according to the use or not of a lever arm.

\begin{tabular}{|c|c|c|c|c|}
\hline \multirow{2}{*}{} & \multicolumn{2}{|c|}{ Good quality rock (fresh rock) } & \multicolumn{2}{c|}{ Bad quality rock (slightly altered) } \\
\cline { 2 - 5 } & With lever arm & Without lever arm & With lever arm & Without lever arm \\
\hline Soft rock & $20-30 \mathrm{~cm}$. & $15-20 \mathrm{~cm}$. & $30-50 \mathrm{~cm}$. & $20-40 \mathrm{~cm}$. \\
\hline Average or hard rock & $15-25 \mathrm{~cm}$. & $10-20 \mathrm{~cm}$. & $25-40 \mathrm{~cm}$. & $-30 \mathrm{~cm}$. \\
\hline
\end{tabular}

\subsection{SUPPORT ROCK OR WALL}

Another important factor when it comes to designing a VF is the rock to be built on. To this end, we need to know the strength of said rock to which the anchorage points are to be attached (compressive strength N/mm2). As a reference, standards EN-959 and UIAA-123 require strength equivalent to that of concrete of over $500 \mathrm{Kg} / \mathrm{cm} 2$ for drilled climbing anchorage points. Different types of rock can be found based on said strength: 
Guide for the Design and Calculation of Via Ferrata

Table 6 Relationship between the quality of the rock and its compressive strength [20]

\begin{tabular}{|c|c|c|}
\hline Quality of the rock & Compressive strength & Examples of rocks \\
\hline Exceptionally hard rock & 1500 to $300 \mathrm{Kg} / \mathrm{cm} 2$ & White and pink quartzite and crystallised basalt. \\
\hline Very hard rock & 800 to $1300 \mathrm{Kg} / \mathrm{cm} 2$ & $\begin{array}{c}\text { White, grey and red granite. Gneiss. Some very grey, } \\
\text { compact limestone }\end{array}$ \\
\hline Hard rock & 500 to $700 \mathrm{Kg} / \mathrm{cm} 2$ & $\begin{array}{c}\text { Grey and dolomitic limestone, certain granite that is } \\
\text { somewhat meteorised or without quartz (Syenite). }\end{array}$ \\
\hline Semi-hard rock & 300 to $400 \mathrm{Kg} / \mathrm{cm} 2$ & $\begin{array}{c}\text { Orange and whitish limestone in large walls, and semi-grey } \\
\text { in shorter cliffs, good quality conglomerate limestone } \\
\text { cement and meteorised gneiss. }\end{array}$ \\
\hline Soft rock & 150 to $250 \mathrm{Kg} / \mathrm{cm} 2$ & $\begin{array}{c}\text { Old limestone, sandstone and very porous volcanic rock, } \\
\text { certain types of schist. }\end{array}$ \\
\hline Very soft rock & 80 to $125 \mathrm{Kg} / \mathrm{cm} 2$ & $\begin{array}{c}\text { Very old limestone, slate, micacite, meteorised and/or } \\
\text { marine sandstone and coquina. }\end{array}$ \\
\hline
\end{tabular}

If the above data is not available we can use visual assessment according to the international rock mechanics society ISRM (1981) which uses a Guide for the design and execution of anchorage points in the land for roadworks:

Table 7 Relationship between the alteration of the rock and its characteristics. [21]

\begin{tabular}{|c|c|c|}
\hline Degree & Term & $\begin{array}{l}\text { Description } \\
\end{array}$ \\
\hline I & Fresh & $\begin{array}{l}\text { No visible signs of alteration of the rock matrix: maybe some slight } \\
\text { discolouration in the surfaces of fractures. }\end{array}$ \\
\hline II & Slightly altered & $\begin{array}{l}\text { Discolouration is indicative of the alteration of the rock matrix and the } \\
\text { surfaces of fractures. All the rocky material may be discoloured due to } \\
\text { alteration and may be softer externally than when fresh. }\end{array}$ \\
\hline III & Moderately altered & $\begin{array}{l}\text { Less than half the rock has decomposed and/or disintegrated into soil. } \\
\text { Fresh or discoloured rock is present both in the fractures and the rock } \\
\text { matrix. }\end{array}$ \\
\hline IV & Very altered & $\begin{array}{c}\text { More than half the rock has decomposed and/or disintegrated into soil. } \\
\text { Fresh or discoloured rock is present both in the fractures and the rock } \\
\text { matrix. }\end{array}$ \\
\hline $\mathrm{V}$ & Completely altered & $\begin{array}{l}\text { All the rock material has decomposed and/or disintegrated into soil. The } \\
\text { structure of the original mass is practically intact. }\end{array}$ \\
\hline VI & Residual soil & $\begin{array}{l}\text { All the rock has transformed into soil. The original structure and material } \\
\text { have been destroyed. There is a change in volume, but the soil has not } \\
\text { been significantly transported. }\end{array}$ \\
\hline
\end{tabular}

If objective data on the quality of the rock is not known and these guidelines are used, only fresh or slightly altered rock will be suitable for the installation of anchorage points (degrees I or II).

\subsection{OTHER RECOMMENDATIONS FOR VF ASSEMBLY}

\subsubsection{ANCHORAGE POINTS}

The spacing of the anchorage points is one of the most important design factors in the whole installation, as this defines the maximum fall factor that can occur in a vertical section. Therefore, this distance must be limited to a maximum of 3-4 metres in vertical sections to avoid fall factors close to two [4]. For horizontal sections, as mentioned in point 6.1 of this article, as a result of the calculations and experiments performed, the establishing of a maximum separation distance of $3 \mathrm{~m}$ is adequate.

Once these distances have been defined, it is recommendable to perform traction testing in a representative percentage which is greater the less certain we are of the good condition of the support rock. Standard UNE-EN795 makes recommendations in point 5.3.4. regarding the testing of lifelines; said testing will take place with a load of $12 \mathrm{kN}$ for 3 minutes, which we also consider to be adequate in the case of VFs [14]. Standard UNE-EN 12572 [24, 25] 
Carlos Martín Díaz, Carlos Mora Sepúlveda, María Dolores Rubio-Cintas and Kissi Benaissa

suggests other loads and testing times but we believe that a VF is more similar to a lifeline than an Artificial Climbing System, hence our preference for standard UNE-EN 795.

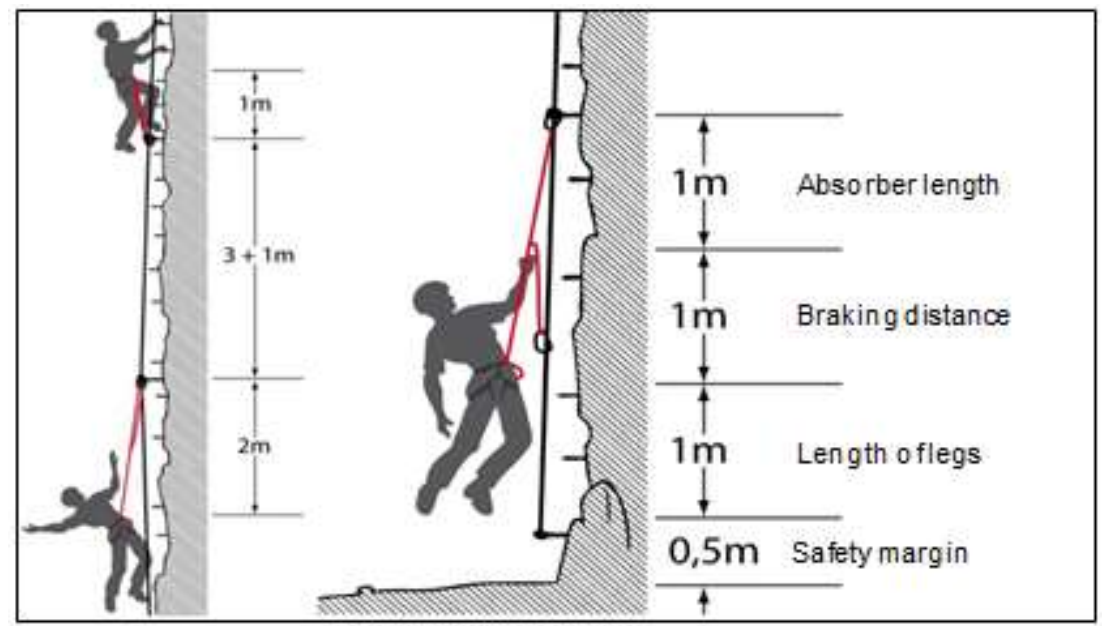

Figure 2 Distances between anchorage points in vertical sections.

The fall factor (FF) is an adimensional number and expresses the severity of a fall. Its value, which falls between 0 and 2 in normal working conditions, is calculated by dividing the height of the fall by the length of the rope/attachment element used.

In the case of VFs, due to the design of the installation and the way of progressing along such, the FF may reach values of 3,4 or even 5 .

\subsubsection{STEPS}

The same methodology as for the anchorage points should be followed for the calculation of steps. The width of these will be a minimum of $20 \mathrm{~cm}$ so that users can put both feet on them, and a maximum of $50 \mathrm{~cm}$ to avoid excessive bending of the step. The distance between the rock wall and the step should be a minimum of $8 \mathrm{~cm}$ and a maximum of $15 \mathrm{~cm}$, thus allowing users to rest their feet on them comfortably and avoiding excessive bending. Finally, for the distance between steps, the recommendation of Royal Decree 486 in Annex I, point 8 [22], should be followed.

\subsubsection{PERMITS AND DOCUMENTATION IN RELATION TO VF}

Before performing any of the VF installations mentioned above in the article, a series of necessary legal permits need to be considered. Firstly, the owner of the land must give written permission for the installation of the VF; next, it must be ensured that this does not go against any town planning by consulting the applicable General Plan for Town Planning (PGOU) and finally, a favourable environmental report is needed (watch out for areas protected by Red Natura 2000). Once all these points have been covered with a favourable outcome, the production of a project supervised by a competent technician, the content of which should follow the recommendations of standard UNE 157001 [23], is more than recommendable. The suggested specific content should include sketches of the route across the land, the type and dimensions of any special elements (zip lines, bridges), the definition of access and exit points of the VF, the characteristics of the materials selected, the minimum signage to be installed, rescue measures to be taken into account and of course, the corresponding calculations. 
Guide for the Design and Calculation of Via Ferrata

\section{CONCLUSIONS}

The sports routes located in forest, peaks, mountains, known as VFs, despite the boom they are currently experiencing, do not have clear guidelines to calculate them. In this article, we have defined the typical VFs and their most important parts. We have gone through the main applicable standards and the technical texts of reference that relate to such, resulting, despite the lack of an international guide, in calculation recommendations for all the elements that make up slightly tightened VFs, namely: the loads to be considered in VFs, the characteristics and sizing of cables, the type and calculation criteria for anchorage points and the spacing of these, steps and the characteristics of the rock or support wall; finally, the minimum documentation considered necessary in relation to VFs is detailed. In any case, we would insist that all these recommendations listed in the article must be supervised during application by qualified, competent technicians with technical qualifications in areas like industrial engineering, whose knowledge allows them to analyse and understand each case and avoid mere literal application of the article.

\section{REFERENCES}

[1] Sánchez Carrasco Daniel. Vías ferratas y caminos equipados. 65 Itinerarios en la Península Ibérica. 1st Edition. Madrid: Ediciones desnivel, 2010. 263p. ISBN: 978-849829-199-5

[2] De Andar. Vías ferratas, senderos y rutas en bicicleta. 2005-2017. Available on the website: <https://deandar.com>. [Checked on: 17th January 2018].

[3] Bressan Giuliano, Melchiorri Claudio, Monteleone Andrea. La sicurezza sulle vie ferrate: Materiali e tecniche. 2nd Edition. Milano: Club Alpino Italiano, 2011. 103p. ISBN: 97888-7982-045-5.

[4] Semmel Chris, Hellberg Florian. Recommendation for the construction of Klettersteigs (also known as via ferrate) and wire cable belay systems. 1st Edition. Munich: German Alpine Club and the Austrian Board of Mountain Safety, 2008. 34p.

[5] AENOR. Equipos de protección individual contra caídas de altura. Arneses anticaídas. UNE-EN 361:2002. Madrid: AENOR, 2002.

[6] AENOR. Cascos de protección para la industria. UNE-EN 397/A1:2000. Madrid: AENOR, 2000.

[7] AENOR. Equipos de montañismo. Cascos para montañeros. Requisitos de seguridad y métodos de ensayo. UNE-EN 12492/A1:2003. Madrid: AENOR, 2003.

[8] AENOR. Equipo de alpinismo y escalada. Mosquetones. Requisitos de seguridad y métodos de ensayo. UNE-EN 12275:2013. Madrid: AENOR, 2013.

[9] AENOR. Equipos de alpinismo y escalada. Sistemas de disipación de energía para uso en escalada vía ferrata. Requisitos de seguridad y métodos de ensayo. UNE-EN 958:2007+A1:2011. Madrid: AENOR, 2011.

[10] ANETVA. Manual de trabajos verticales. Madrid: ANETVA, 2006. ISBN: 84-611-36780 .

[11] AENOR. Estructuras de deporte y actividades recreativas. Recorrido acrobático en altura. Parte 1: Requisitos de construcción y seguridad. UNE-EN 15567-1:2015. Madrid: AENOR, 2015.

[12] AENOR. Equipos de alpinismo y escalada. Anclajes para roca. Requisitos de seguridad y métodos de ensayo. UNE-EN 959: 2007. Madrid: AENOR, 2007.

[13] AENOR. Cables de acero. Seguridad. Parte 1: Requisitos generales. UNE-EN 123851:2003+A1:2008. Madrid: AENOR, 2008.

[14] AENOR. Equipos de protección individual contra caídas. Dispositivos de anclaje. UNEEN 795:2012. Madrid: AENOR, 2008. 
Carlos Martín Díaz, Carlos Mora Sepúlveda, María Dolores Rubio-Cintas and Kissi Benaissa

[15] AENOR. Equipos de protección individual contra caídas de altura. Parte 2: Dispositivos anticaídas deslizantes sobre línea de anclaje flexible. UNE-EN 353-2:2002. Madrid: AENOR, 2002

[16] AENOR. Equipos de protección individual contra caídas de altura. Dispositivos anticaídas deslizantes sobre línea de anclaje. Parte 1: Dispositivos anticaídas deslizantes sobre línea de anclaje rígida. UNE-EN 353-1:2014. Madrid: AENOR, 2014.

[17] AENOR. Equipamiento de las áreas de juego y superficies. Parte 4: Requisitos de seguridad y métodos de ensayo adicionales específicos para tirolinas. UNE-EN 11764:2009. Madrid: AENOR, 2009.

[18] National Statistics Institute. 2017. Available on the website: <http://www.ine.es>. [Checked on: 17th January 2018].

[19] TYCSA. Trenzas y cables de acero. Catálogo general. Barcelona, 1962.

[20] Castaño Boza J. Alberto. Anclajes para escalada. 1st Edition. Principality of Asturias: Ediciones Cordillera Cantábrica, 2016. 112p. ISBN: 978-84-943399-7-4.

[21] Ministry of Development. Directorate General for Roads. Guía para el diseño y la ejecución de anclajes al terreno en obras de carreteras. 2nd Edition. Madrid, 2003. 53p. ISBN: 84-498-0667-4.

[22] ROYAL DECREE 486/1997, of 14 April, to establish the minimum health and safety provisions for workplaces. BOE no.97 23/04/1997.

[23] AENOR. Criterios generales para la elaboración formal de los documentos que constituyen un proyecto técnico. UNE-EN 157001:2014. Madrid: AENOR, 2014.

[24] AENOR. Estructuras artificiales de escalada. Parte 1: Requisitos de seguridad y métodos de ensayo para SAE con puntos de protección. UNE-EN 12572-1:2017. Madrid: AENOR, 2017.

[25] AENOR. Estructuras artificiales de escalada. Parte 2: Requisitos de seguridad y métodos de ensayo de los muros de escalada. UNE-EN 12572-2:2017. Madrid: AENOR, 2017. 